\title{
Introduction: Critical Prison Studies, Carceral Ethnography, and Human Rights: From Lived Experience to Global Action
}

\author{
SARAH TURNBULL* \\ J OANE MARTEL* \\ DEBRA PARKES* \\ DAWN MOORE*
}

Turnbull, S., Martel, J., Parkes, D. and Moore, D., 2018. Introduction: Critical Prison Studies, Carceral Ethnography, and Human Rights: From Lived Experience to Global Action. Oñati Socio-legal Series [online], 8 (2), 174-182. Available from: https://doi.org/10.35295/osls.iisl/0000-0000-0000-0934

\begin{abstract}
This collection of essays grew out of the workshop Critical Prison Studies, Carceral Ethnography, and Human Rights: From Lived Experience to Global Action held at the International Institute for the Sociology of Law (Oñati, Spain) in June 2016. The papers explore some of the challenges and possibilities of critical prison research, ranging from issues arising in university research ethics reviews to the limitations of penal reform efforts to end the practice of solitary confinement. Each essay is embedded in a different penal context: Australia, Italy, Russia, Canada, and the United States; and each contributes to broader discussions of critical prison research, utilizing new and old methods and sources, including the netnography of prisoner websites and the archives of anti-carceral feminist campaigners. Collectively, the essays bring new insights and methods into scholarly and activist conversations aimed at understanding and responding to the harms of incarceration.
\end{abstract}

\section{Key words}

Human rights; incarceration; critical research; prison ethnography; critical prison studies

\section{Resumen}

Esta colección de ensayos se originó del seminario Critical Prison Studies, Carceral Ethnography, and Human Rights: from Lived Experience to Global Action, celebrado en el Instituto Internacional de Sociología J urídica (Oñati, España), en junio de 2016. Los artículos analizan algunos de los desafíos y de las posibilidades de la investigación

We thank the contributors to this special issue and Leire Kortabarria and Cristina Ruiz of the International Institute for the Sociology of Law.

* Sarah Turnbull is Lecturer in Criminology in the School of Law, Birkbeck, University of London, United Kingdom. Email address: sarah.turnbull@bbk.ac.uk.

* J oane Martel is Professor of Criminology in the School of Social Work and Criminology, Université Laval, Canada. Email address: joane.martel@tsc.ulaval.ca.

* Debra Parkes is Professor and Chair in Feminist Legal Studies in the Peter A. Allard School of Law, The University of British Columbia, Canada. Email address: parkes@allard.ubc.ca

* Dawn Moore is Associate Professor of Law and Legal Studies in the Department of Law and Legal Studies, Carleton University, Canada. Email address: dawnmoore@cunet.carleton.ca.

\section{(cc) EY-NC-ND}

Oñati International Institute for the Sociology of Law Antigua Universidad s/n - Apdo.28 20560 Oñati - Gipuzkoa - Spain 
crítica penitenciaria, desde problemas relativos a la revisión ética de la investigación en universidades a las limitaciones de las reformas penales para acabar con el confinamiento aislado. Cada artículo tiene un contexto penal diferente - Australia, Italia, Rusia, Canadá y los Estados Unidos - y cada uno realiza una aportación al debate sobre la investigación crítica penitenciaria, utilizando métodos y fuentes que incluyen la netnografía de sitios web de prisioneros y los archivos de feministas anticarcelarias. Se aportan nuevos métodos y visiones a la conversación académica y activista encaminada a responder a los perjuicios del encarcelamiento.

\section{Palabras clave}

Derechos humanos; encarcelamiento; investigación crítica; etnografía de la prisión; estudios penitenciarios críticos 


\section{Table of contents / Í ndice}

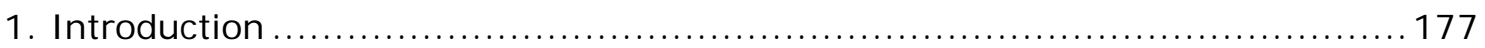





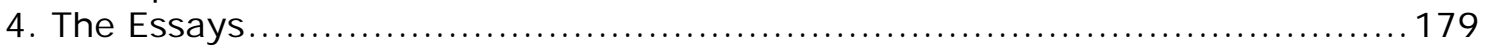

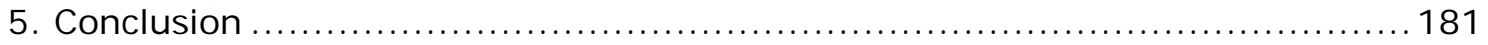

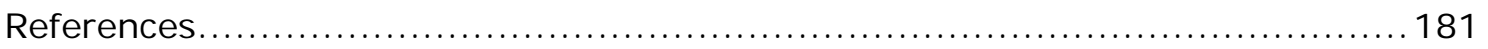




\section{I ntroduction}

Scholarly discussions of human rights in the punishment and society and prison studies literatures tend to focus on the meanings of cruel, inhumane, or degrading treatment and the right to be treated as a human and with dignity (Liebling 2011). Legal and policy scholars often frame the problem of human rights as an enforcement issue (Jackson 2002) or focus on the paradox of procedural justice wherein substantive human rights are rarely, if ever, realized by the recipients (van Zyl Smit 2013). Still others (e.g., Mackay 2014) focus on semantics, cultural shifts, the need for officer training, and better selection and screening processes to ensure guards and managers comply with the law. Abolitionist scholars argue that prison researchers have an obligation to "bear witness to what happens behind the doors of closed institutions" (Scraton and McCulloch 2009, p. viii), while cautioning against prison research and legal reform efforts that may serve to reinforce carceral logics and retrench practices of imprisonment (Parkes 2017). Scholars like Merry show how exercising human rights requires extensive legal expertise, resources, and networks often not readily available to marginalized groups (Merry et al. 2010), such as incarcerated people. Empirical socio-legal scholarship reveals important variations in legal contexts that affect legal mobilizations and human rights claims (Calavita and J enness 2013). Consequently, it is important to explore various legal contexts and carceral spaces, such as segregation cells and immigration detention centres, to open up a more complex and nuanced conversation about rights abuses and carceral transparency.

\section{Neoliberal Penality}

If one believes that what happens inside prisons impacts notably on the quality of prisoners' community resettlement, then one ought to care about prison performance and government or citizen oversight. Prison performance is a rapidly developing concept and practice that has been linked to the economy and to public sector transformations. Since the early 1980s, fundamental socio-economic changes have been altering societies both in the global north and in the global south. Be it the end of the Cold War, the development of a global economy, or the neoliberal and neoconservative turns which swept almost simultaneously several countries, pressures on national governments to transform their own public sectors increased under growing evidence of the failing of interventionist economic policies. In the midst, economic pressures toward radical public management reform began to surface in order to reduce large budget deficits.

Such transformations have led to the emergence of what has been termed the new public management, a broad - and contestable - generic concept used to describe the recent process by which a series of "administrative techniques and strategies, commonly associated with the private sector, infiltrate into arenas more readily described as public" (Fitzpatrick et al. 2000, p. 8). Also referred to as "public sector managerialism" (e.g., Raine and Willson 1997), this generic term is used habitually to describe a wave of recent public-sector reforms undertaken by national states throughout the global north in an effort to modernize themselves - that is, to streamline their bureaucracies and spend fewer taxpayer dollars while providing more effective services. Closely intertwined with neoliberal tenants, the new public management (NPM) similarly promotes reduced program spending and market involvement in service delivery (O'Brien 2006). Among its particular characteristics, this management ethos is marked by: (1) an emphasis on economy, efficiency, and effectiveness; (2) the desire to satisfy 'consumer' needs; (3) the involvement of the private sector; (4) the measurement and audit of agency performance; and (5) the comparison of performance between various service providers (Fitzpatrick et al. 2000). Hence, public sector efficiency is believed to be enhanced through competition (i.e., contracting out to private providers of services) and a better maximization of public budget, as well as accurate and standardized measures of organizational performance. 
Although it remains difficult to pinpoint the exact genesis of NPM, New Zealand and the United Kingdom (UK) are usually regarded as the pioneer users of NPM philosophy in the public sector as early as the 1980s (Borins 2000). The United States (US) as well as Canada have begun more recently to experiment with this particular social organization of government management. In the US, the 1993 Government Performance and Results Act ${ }^{1}$ marked the US political determination to demand and measure the performance of the public service. Specifically, it requires all government departments to establish key performance indicators and measure their progress in meeting them.

In Canada, the distinctive shift in the way public administration was both viewed and managed began to occur in the 1980s when former Prime Minister Brian Mulroney advocated private sector management techniques and principles to curtail growing academic, media, and Auditor General allegations of governmental mismanagement of the public purse (Cooper and Ogata 2005). At the dawn of the 1991 recession, more specifically, several levels of government were feeling the increasing pressure of NPM-based discourses to keep in check deficits that were taking colossal proportions. By the mid-1990s, indeed, capital markets' perception of Canada's fiscal order darkened, thereby leading bond rating agencies to downgrade both federal and provincial debts. Following years of feeble reforms to curb spending and debt, and streamline the public service sector, the key reform came in 1994/95 under the Liberal government of former Prime Minister J ean Chrétien, with the Program Review exercise whose magnitude and severity produced dramatic changes within the budget and structure of government, consequently guiding the Canadian state directly into a result-based management culture (Savoie 1999).

In the midst of this wave of managerialist reforms, criminal justice state agencies and institutions have not been spared. Rather, they have been undergoing various transformations to bring them in line with the new managerialist ethos. In England and Wales, for example, the introduction of new modes of "court management" (Fitzpatrick et al. 2000) or the implementation of compliance audits, and rating scales, of prisons' performance (Liebling 2004) have both operationalized the NPM into measurable criteria. Similarly, US prison executives have been increasingly using result-driven (performance-based) management to assure accountability by translating agency missions into measurable outcomes, setting performance targets, and monitoring performance toward quality improvement of services (Wright 2005).

In applying ideas borrowed from the business world, public sector reforms related to criminal justice have predominantly retained notions of performance and accountability (of policy managers and practitioners) as major components of a new style of managing criminal justice. In this regard, several national governments, in Canada and elsewhere, may be considered most advanced in their implementation of this managerialist ethos, and its operationalization into managerialist practices. The uptake of the NPM has translated into strategic or business plans, privatization of services (e.g., correctional services), measurement of standardized key performance indicators (such as public perception of safety in the home, violent crime rates, number of escapes from secure custody, and access to victim service units), information management databases, and program evaluation research to enlighten program performance. Often referred to as state modernization, recent efforts at operationalizing the NPM - through performance-based management - have also been sketched into discourses of accountability and transparency. On a semiotic level, linking state modernization with accountability and transparency tends to relegate the times preceding this modernization to a more irresponsible, opaque era.

Despite such discourses of (and claims to) accountability and transparency, carceral sites remain, by and large, hidden and in some cases, impervious to outside scrutiny.

\footnotetext{
${ }^{1}$ An Act to provide for the establishment of strategic planning and performance measurement in the Federal Government, and for other purposes (1993) No. 103-62.
} 
In some countries, such as Canada, there is currently little systematically collected national data to describe prisoner experiences, including experiences in attempting to access mechanisms of accountability and remedy (Martel 2004, cf. Hannah-Moffat 2010). Nor is there much experiential data to support Canadian corrections' newly found transparency. Research access is tightly controlled, as are the kinds of questions researchers can ask. Other countries, though, such as the UK, are characterized by greater carceral transparency with well-established inspection and monitoring systems (both public and private) as part of prison accountability and governance regimes (Behan and Kirkham 2016). Late modern ethnographic studies (e.g., Crewe 2009) describe every aspect of prison life as tenuous and uneasy, yet gaining access to carceral sites to undertake such research is difficult even though it is needed (Wacquant 2002). Liebling (2006) suggests that despite twenty years of progressive prison philosophy in the UK, evaluative or metric-based governance has undermined the importance of understanding day-to-day experiences of incarceration. Regardless of the intention to measure the uses of correctional authority to ensure transparency, fairness, and accountability, such objectives have been overshadowed by the complex, productive, and nuanced relationships between staff and inmates.

\section{The Special I ssue}

This special issue contains several of the papers presented and discussed during the workshop Critical Prison Studies, Carceral Ethnography, and Human Rights: From Lived Experience to Global Action held at the International Institute for the Sociology of Law (Oñati, Spain) in J une 2016. The workshop stemmed from a specific research program, the Prisons Transparency Project, ${ }^{2}$ which sought to document the conditions of confinement in Canadian prisons and immigration detention centres using participatory action-based research with persons with lived experience of incarceration. Although the workshop was not focused solely on the Prisons Transparency Project, the project team was keen to have the opportunity to bring together scholars working in the areas of critical prison and migrant detention research for two days of dialogue and discussion from critical perspectives. The sessions explored issues of confinement in and across a diverse range of jurisdictions: Australia, Canada, Denmark, India, Italy, Japan, the Philippines, Portugal, Russia, Spain, the United Kingdom, and the United States. The workshop was organized around two main themes: (1) how issues related to human rights are experienced in carceral contexts and how violations are differentially framed in advocacy, law, and administrative practices; and (2) how we can understand and make evident rights violations that are rarely visible due to the closed character of prisons and other sites of confinement. Particular attention was paid to methodological and theoretical concerns, including the role of critical researchers in studying the often-hidden worlds of incarceration.

\section{The Essays}

The first three essays, written by Laura Piacentini and Elena Katz, Luigi Gariglio, and Gillian Balfour and Joane Martel, respectively, address methodological and epistemological questions in critical prison research. Beginning with The Virtual Reality of Imprisonment: The Impact of Social Media on Prisoner Agency and Prison Structure in Russian Prisons, Piacentini and Katz consider Russian prisoners' engagement with social media and the impact this online activity has on agency and structure. Drawing on findings from an innovative netnography (online ethnography) of prisoner websites in Russia, the essay explores how Russian penality is simultaneously, and paradoxically, characterised by visibility and hiddenness.

\footnotetext{
2 This project is generously funded by the Social Sciences and Humanities Research Council through a Partnership Development Grant [no. 890-2014-0034]. The project is led by Dawn Moore (PI), Gillian Balfour, Kelly Hannah-Moffat, Joane Martel, Debra Parkes, and Sarah Turnbull, along with a team of excellent research assistants, community partners, and persons with lived experience of incarceration.
} 
Prisoners, Piacentini and Katz argue, have an absent presence. Through prisoners' online engagement, the prison exists beyond its physical space (it is deinstitutionalised) while prisoners unmake their absence from society (they reterritorialise their hidden bodies). Notably, the essay shows how prisoners' use of the internet has important implications for self-expression, producing what Piacentini and Katz call "a new penal imaginary" (p. 183) in the form of an online world.

Gariglio's essay Doing (Prison) Research Differently: Reflections on Autoethnography and 'Emotional Recall' underscores the emotional challenges of conducting ethnographic prison research and how the unorthodox method of autoethnography enabled him to explore new facets of prison officer-prisoner relationships in his Italian field site. Critically assessing autoethnography as a novel social research method, Gariglio shows how the methodological tool of emotional recall can be used to process emotionally difficult research experiences and think differently about previously unexplored ethnographic data. This reflexive process yielded an important finding about prison officers' preferential treatment of Mafioso prisoners. In the context of critical prison research, this essay offers an innovative methodology for working through, and thinking differently, about ethnographic data.

For university researchers, methodological issues are always infused with ethical questions and the very pragmatic hurdle of university ethics review processes. In their essay Critical Prison Research and University Research Ethics Boards: Homogenization of Inquiry and Policing of Carceral Knowledge, Balfour and Martel provide two case studies critically examining the "interpretive authority" of university research ethics boards in making decisions about ethical reviews. As co-investigators on the Prisons Transparency Project, Balfour and Martel detail how the project, originally designed to utilize a participatory action-based research methodology, was transformed by the ethical review processes at two Canadian universities, thus raising important questions about the role of research ethics boards in policing critical prison research. The essay discusses two challenges that emerged from the ethics review process: one involved stereotypical bias about the perceived risk of former prisoners, both as co-researchers and participants, while the second concerned a board's cautious interpretation and application of federal ethical guidelines, resulting in the exclusion of Indigenous peoples from the project. Balfour and Martel highlight the important implications of these experiences for critical prison research as well as the need for researchers to also consider ethics boards as potential sites of scholarly enquiry.

The final two essays in the collection interrogate the challenges and potential of critical prison research to prison reform and abolitionist projects. Keramet Reiter's essay The International Persistence and Resilience of Solitary Confinement assesses how solitary confinement remains a common feature of prisons around the world, despite over a century and a half of concern and criticism about the practice. Carefully detailing both the pervasiveness and persistence of solitary confinement, she shows how the practice is stubbornly resilient in the face of extensive court challenges, international conventions, academic research, and third sector legal advocacy work that confirms its detrimental effects. This is true of systems that are notorious for being excessive and harsh (the US) and those that are presumed to be humane (Denmark). For Reiter, the "persistent resilience" of solitary confinement must be situated in broader histories of penal reform and how approaches to ending the practice, described as reformist (seeking to make improvements) and non-reformist (radical and critical critiques favouring abolition), differently challenge the practice. Importantly, for critical prison research, this essay demonstrates the limitations of penal reform strategies, including litigation, to bring about an end to detrimental penal practices. It is necessary to think differently and ask new questions.

In 'We Will be Written Out of History': Feminist Challenges to Carceral Violence and the Activist Archive, Bree Carlton and Emma Russell show how anti-carceral activist archives are key sites for critical prison research and action. Drawing on feminist 
campaign materials on the segregation of women prisoners in maximum-security men's prisons from the 1980s and early 1990s in the Australian State of Victoria as a case study, they demonstrate the importance of activist knowledge productions to disrupt and challenge dominant carceral logics and official discourses. The conceptual and methodological significance of the activist archive, Carlton and Russell argue, is a deeper understanding of anti-carceral feminisms and of the "value of activist knowledge transfer and continued vigilance in the face of historical cycles of reform and punishment" (p. 270). Importantly, this essay underscores the immense potential of activist archives as resources for critical prison research.

\section{Conclusion}

Together, the essays comprising this special issue provide a range of perspectives on the possibilities and challenges of doing critical prison research. In so doing, the contributors also critically interrogate their own research practices, sources, and epistemologies. They bring new insights and methods into scholarly and activist conversations aimed at understanding and responding to the harms of incarceration.

\section{References}

Behan, C., and Kirkham, R., 2016. Monitoring, inspection and complaints adjudication in prison: the limits of prison accountability frameworks. The Howard journal of crime and justice [online], 55 (4), 432-454. Available from: https://doi.org/10.1111/hojo.12184 [Accessed 21 May 2018].

Borins, S., 2000. New public management, North American style. In: K. McLaughlin, S. Osborne and E. Ferlie, eds., New public management: current trends and future prospects. London: Routledge, 181- 194.

Calavita, K., and Jenness, V., 2013. Inside the pyramid of disputes: naming problems and filing grievances in California prisons. Social problems [online], 60 (1), 50-80. Available from: https://doi.org/10.1525/sp.2013.60.1.50 [Accessed 21 May 2018].

Cooper, D.J., and Ogata, K., 2005. New public management reforms in Canada: success or failure? In: J. Guthrie et al., eds., International public financial management reform: progress, contradictions, and challenges. Greenwich, CT: Information Age Publishing, 55-86.

Crewe, B., 2009. The prisoner society: power, adaptation and social life in an English prison. Oxford University Press.

Fitzpatrick, B., et al., 2000. New courts management and the professionalisation of summary justice in England and Wales. Criminal law forum, 11 (1), 1-22.

Hannah-Moffat, K., 2010. Criminological cliques: narrowing dialogues, institutional protectionism and the next generation. In: M. Bosworth and C. Hoyle, eds., What is criminology? Oxford University Press, 440-455.

Jackson, M., 2002. Justice behind the walls: human rights in Canadian prisons. Vancouver: Douglas \& Mclntyre.

Liebling, A. (assisted by Arnold, H.), 2004. Prisons and their moral performance: a study of values, quality and prison life. Oxford University Press.

Liebling, A., 2006. Prisons in transition. International Journal of Law and Psychiatry [online], 29 (5), 422-430. Available from: https://pdfs.semanticscholar.org/cd4c/617c28a73f15237c7c8afd8230871bdb6 623.pdf [Accessed 21 May 2018].

Liebling, A., 2011. Moral performance, inhuman and degrading treatment and prison pain. Punishment \& Society [online], 13 (5), 530-550. Available from: 
http://journals. sagepub.com/doi/abs/10.1177/1462474511422159 [Accessed 21 May 2018].

Mackay, A., 2014. Operationalising Human Rights Law in Australia: Establishing a Human Rights Culture in the New Canberra Prison and Transforming the Culture of Victoria Police. Law in context, 31 (1), 261-294.

Martel, J., 2004. Policing Criminological Knowledge: the Hazards of Qualitative Research on Women in Prison. Theoretical criminology [online], 8 (2), 157189. Available from: http://journals. sagepub.com/doi/abs/10.1177/1362480604042242 [Accessed 21 May 2018].

Merry, S.E., et al., 2010. Law from Below: Women's Human Rights and Social Movements in New York City. Law and Society Review, 44 (1), 101-128.

O'Brien, D., 2006. Post-bureaucracy or Post-public Good? New Public Management and the Policy Process Constraints in Ontario [online]. Ontario Legislature Internship Program. Canadian Political Science Association, 2 J une. Available from: https://www.cpsa-acsp.ca/papers-2006/0\%27Brien.pdf [Accessed 21 May 2018].

Parkes, D., 2017. Solitary Confinement, Prisoner Litigation, and the Possibilities of a Prison Abolitionist Lawyering Ethic. Canadian Journal of Law and Society [online], 32 (3), 165-185. Available from: https://doi.org/10.1017/cls.2017.16 [Accessed 21 May 2018].

Raine, J.W., and Willson, M.J., 1997. Beyond Managerialism in Criminal Justice. The Howard J ournal of Crime and J ustice 36 (1), 80-95.

S. 20 - 103rd Congress: Government Performance and Results Act of 1993 [online]. Available from: https://www.govtrack.us/congress/bills/103/s20 [Accessed 21 May 2018].

Savoie, D.J., 1999. Governing from the Centre: the Concentration of Power in Canadian Politics. University of Toronto Press.

Scraton, P., and McCulloch, J., eds., 2009. The Violence of Incarceration. New York: Routledge.

van Zyl Smit, D., 2013. Punishment and human rights. In: J. Simon and R. Sparks, eds., The SAGE handbook of punishment and society. London: Sage, 395-425.

Wacquant, L., 2002. The Curious Eclipse of Prison Ethnography in the Age of Mass Incarceration. Ethnography [online], 3 (4), 371-397. Available from: http://journals.sagepub.com/doi/10.1177/1466138102003004012 [Accessed 21 May 2018].

Wright, K.N., 2005. Designing a National Performance Measurement System. Prison journal [online], 85 (3), 368-393. Available from: http://dx.doi.org/10.1177/0032885505279389 [Accessed 21 May 2018]. 